\title{
Image directed lymph node sampling for lung cancer staging
}

\author{
Leslie E Quint, Douglas Arenberg, Rishindra M Reddy, Jules Lin \\ From International Cancer Imaging Society (ICIS) 14th Annual Teaching Course \\ Heidelberg, Germany. 9-11 October 2014
}

\section{Educational poster objectives}

- To display methods of regional lymph node sampling for staging bronchogenic cancer.

- To illustrate how imaging directs the optimal methods of sampling in individual patients.

\section{Introduction}

- Summarize the lung cancer staging system.

- Show regional lymph node stations using diagrams and CT/PET images.

- Explain the need for tissue sampling in order to establish the highest stage and direct appropriate therapy. Sampling techniques with illustrations and imaging examples of accessible lymph nodes:

- Mediastinoscopy: Gold standard; outpatient surgical technique; optimal for stations 2, 4, and 7; tissue samples from all available nodal stations.

- Transbronchial needle aspiration (TBNA) with endobronchial ultrasound (EBUS): Optimal for stations 2, 4, 7, 10-12; often only abnormal nodes sampled; cytologic sample; least invasive; not universally available.

- Chamberlain procedure: Outpatient surgical technique; historical standard for stations 5 and 6; tissue samples.

- Video assisted thoracoscopic surgery (VATS): Surgical technique; optimal for stations $2 \mathrm{R}, 4 \mathrm{R}, 5,6,7,8,9,10$, and 11; tissue samples; supplanting Chamberlain procedure; must tolerate single lung ventilation.

- Endoscopic ultrasound (EUS): Optimal for stations 3p, 4L, 7, 8, 9, and occasionally 3a, 2R, 2L, 4R; cytologic sample; not universally available.

- CT guided biopsy: not routine; different approaches (e.g. parasternal) and patient positioning; optimal for large nodes; core biopsy.

* Correspondence: lequint@umich.edu

University of Michigan, Ann Arbor, MI, USA

\section{Summary}

In patients with lung cancer, choosing a method of lymph node sampling depends on anatomy, availability of techniques, amount of tissue needed, cost, and safety. CT and PET imaging are crucial for depicting anatomical relationships and directing the appropriate sampling technique.

Published: 9 October 2014

doi:10.1186/1470-7330-14-S1-P32

Cite this article as: Quint et al:: Image directed lymph node sampling for lung cancer staging. Cancer Imaging 2014 14(Suppl 1):P32.

Submit your next manuscript to BioMed Central and take full advantage of:

- Convenient online submission

- Thorough peer review

- No space constraints or color figure charges

- Immediate publication on acceptance

- Inclusion in PubMed, CAS, Scopus and Google Scholar

- Research which is freely available for redistribution

Submit your manuscript at www.biomedcentral.com/submit
() Biomed Central

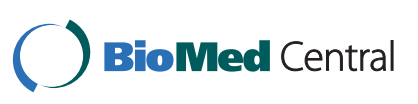

